\title{
PAUL BOWLES: TRANSLATING FROM TANGIER
}

\author{
Allen Hibbard \\ Middle Tennessee State University. Department of English, \\ Murfreesboro, USA.
}

\begin{abstract}
This essay examines the complex relationships between American writer Paul Bowles and Moroccan writers/storytellers whose works he translated (Ahmed Yacoubi, Larbi Layachi, Mohammed Mrabet, and Mohamed Choukri), with attention to reasons for Bowles's turn to translation, the unique character of his translations of oral stories, the status of the "original" in these cases, as well as the surrounding postcolonial and Orientalist contexts of this translation activity. It advances the notion that Bowles's translation activity is at once collaborative, dialogic, and mutually beneficial, motivated by the translator's genuine interest in preserving and making more widely available local cultural production that might otherwise have gone unnoticed and unrecorded.
\end{abstract}

Keywords: Exile. Translation. Postcolonial condition. Paul Bowles. Contemporary Moroccan Literature.

\section{PAUL BOWLES: TRADUIRE DEPUIS TANGER}

Résumé: Cet essai examine les relations complexes existant entre l'écrivain américain Paul Bowles et les écrivains ou conteurs marocains, notamment Ahmed Yacoubi, Larbi Layachi, Mohammed Mrabet, and Mohamed Choukri, dont Bowles a traduit les textes. Tout en prenant en compte les contextes postcoloniaux et orientalistes qui président à cette traduction, l'auteur de cet essai porte une attention particulière aux raisons ayant amené Bowles à la traduction, au caractère unique de ses traductions d'histoires orales, et au statut d' "originaux" de ces textes. Cet essai propose que l'activité de traduction de Bowles est à la fois collaborative, dialogique, et mutuellement avantageuse, ainsi que motivée par l'intérêt 
sincère du traducteur de préserver et de disseminer cette production culturelle locale qui sinon aurait pu demeurer inaperçue et non documentée. Mots-clés: Exil-Traduction-Condition postcoloniale-Paul Bowles-Littérature marocaine contemporaine.

"I think translations are as difficult to do as invention." Paul Bowles, Interview The Cage Door Is Always Open (documentary, dir. Daniel Young, 2013)

American writer Paul Bowles lived in Tangier, Morocco more or less continuously from 1947 until his death in 1999. During the first couple of decades in exile, Bowles devoted most of his creative energies to his own fiction, producing dozens of stories and several novels set in North Africa (The Sheltering Sky 1949; Let It Come Down 1952; and The Spider's House 1956). By the 1960s, however, the writer was turning his attention more and more to translation projects. From 1964 to 1992, he translated no fewer than fifteen volumes of fictional work by local Moroccan storytellers and writers, including Ahmed Yacoubi, Larbi Layachi, Mohammed Mrabet, and Mohamed Choukri. All, except for Choukri, worked solely in the oral tradition; thus his mode of translation (usually from tape) was unconventional. My focus here is on Bowles's turn to translation, with attention to the complicated issues (practical, political, erotic, economic) surrounding his translation activity, the status of "original" text, the effect of his translation on his own work, and-more broadly-the wider cultural scenes, all revolving around the condition of exile. It is my hope that this exploration will lead to a deeper understanding of the particularities of Bowles's own translation enterprise as well as the important relationship between translation and exile. As well, this focus on his work in translation enriches our appreciation of the breadth of Bowles's creative endeavors, allowing us to see integral connections between his musical composition, his writing, his recordings of found sound and Moroccan music, and his translations. 
A number of contributing factors help explain Bowles's move toward translation, including his wife Jane's declining health (following a stroke in the late 1950s), development of friendships with Moroccan storytellers, and (some have speculated) a drying up of the well of his own imagination. His interest in storytellers in the oral tradition was consistent with his attraction to a pre-modern Morocco that he saw jeopardized by postcolonial nationalism and forces of modernization, a philosophy that, as John Maier puts it, was "an indicator of much that has changed in the Western view of the non-Western world" (214). Bowles translated because, in his words, "I thought it would perhaps shed light on the culture that was much despised. I thought it probably did" (qtd. in Bejjit, 119). His translation projects thus seem to have been motivated by the same kinds of concerns and interests that lay behind his interest in preserving indigenous Moroccan music. In 1959, around the time he began to turn his attention to translation, Bowles traveled around Morocco recording local, traditional music of various traditions and genres. At the time he felt an urgent need to preserve this music that was threatened by popular, mass-produced music in both the Arab world and the West.

These ethnomusicological and translation projects, significantly, both relied on the use of the tape recorder. In a piece titled "The Rif, to Music," in Their Heads are Green Their Hands are Blue, Bowles describes some of the ordeals and adventures that accompanied the taping of indigenous music, as Bowles, his Canadian artist friend Christopher Wanklyn, and their Moroccan assistant Mohammed Larbi traveled through back roads and mountainous terrain of northern Morocco in Wanklyn's VW Beetle. The crew captured around 250 examples of music from 22 locations on their Ampex 601 recording machine, selections which recently have been reproduced in a 4-CD set, Music of Morocco. And at about the same time (probably about a year earlier, in 1958), Bowles's innovative experimentation with the tape recorder led to the creation of a superb example of musique concrète, available in a recent re-release of the $\mathrm{CD}$, The Pool, K III. All of these 
productions-both in music and translation-owe their existence to a fortuitous confluence of elements involving Bowles, the local scene in Morocco, and use of available technology.

Bowles's translation work, particularly with storytellers, was rooted in personal connections made possible only because of his life as an exile in Tangier. First among these local collaborators was Ahmed Yacoubi, one of the writers included in Five Eyes, a collection of stories from five Moroccan storytellers that contains some of Bowles's earliest translations. Bowles recounts how he came upon the young Moroccan in Fez in the late 1940s, took him under his wing, and encouraged him to paint. Later Bowles took him on trips to Sri Lanka [then Ceylon] and Istanbul. It is generally assumed that the two were, at one point at least, lovers. Yacoubi "did not speak any French, any Spanish, and ... no English," Bowles noted. "He spoke a very strange Darija [Moroccan dialect]" (qtd. in Bischoff, 224).

Then in 1962 Bowles met Larbi Layachi, a fisherman who, like Yacoubi, was illiterate. Their collaboration resulted in an autobiographical novel, A Life Full of Holes. This was followed by the longest sustained and most productive collaborative relationship, with Mohammed Mrabet, who Bowles met after watching the young man, strong and athletic, doing acrobatics on Merkala Beach in Tangier. As the story goes, Mrabet heard about Layachi's book, and proposed a similar project to Bowles, saying he had many stories to tell. The relationship between the two lasted from the 1960s into the 1990s, when apparently tensions rose, during the last years of Bowles's life. In Look and Move On, Mrabet describes the translations: "Some were tales I have heard in the cafés, some were dreams, some were inventions I made as I was recording, and some were about things that had actually happened to me" (91).

Bowles, himself unable to read and write Arabic, stood in relation to the dominant written Arabic culture much as did those storytellers whose work he translated. All three of these collaborations thus were infused with a childlike innocence associated with the premodern, a relation to life and story unmediated by writing-at least until Bowles entered the scene and gave those stories written 
form. "I am inclined to believe that illiteracy is a prerequisite," Bowles has said. "The readers and writers I have tested have lost the necessary immediacy of contact with the material. They seem less in touch with both their memory and their imagination than the illiterates" (qtd. in Stewart, 112). These remarks are strikingly similar to comments he made about musicians, in his introduction to the 1972 LP set of his recordings of Moroccan music: "the very illiteracy of the people through the centuries has abetted the development of music" (Music of Morocco).

The process by which Bowles translated these oral stories was distinctive, unlike the process usually followed when moving a written text from one language to another. Stories were told to Bowles, improvised, and taped, often in one sitting. Bowles at times took notes. The fluidity and variation of oral stories is solidified as they are transcribed. Bowles thus became the first writer of these texts, often editing them heavily to suit the new medium and audience. Even when he translated the work of Mohamed Choukri, which existed in written form prior to translation, he employed similar techniques. In his introduction to the translation of Choukri's novel For Bread Alone, Bowles writes that the novel was "written in Arabic, a language I do not know. The author had to reduce it first to Moroccan Arabic for me. Then we used Spanish and French for ascertaining shades of meaning. Although exact, the translation is far from literal" (5). In the translator's introduction to Five Eyes, Bowles wrote: "had I known how difficult it would be to make English translations of Mohamed Choukri's texts, I doubt that I should have undertaken the work," adding that "It was Choukri himself who was obliged to do the translating, sometimes working through the medium of the colloquial Darija, but generally through Spanish, and occasionally even French." He goes on, saying that "After Choukri, it was a relief to return to the smooth-rolling Mrabet translations" because, unlike Choukri, Mrabet "has no thesis to propound, no grievances to air, and no fear of redundant punctuation" (8). Distinguishing his writing from the "telling" of Moroccan storytellers, Choukri writes in Paul Bowles wa "uzla 
Tanja: "I don't tell my stories; I write them for those who can read but Mrabet does not write, he only narrates and Paul writes his stories. And a story must change once it is written" (118). Bowles no doubt felt less constrained and more at ease transcribing or translating oral stories than written ones. He was clearly more at home in the spoken language of Morocco than formal Arabic. And short of going back to tapes and comparing them to Bowles's finished stories, there was no way to gauge how faithful he had been to the "original."

Similar to the means by which 1001 Nights was produced, as oral stories were gathered and recorded in writing, Bowles's translation becomes the "original." And, as in the case of 1001 Nights and other instances where oral stories have been transferred into writing, we might ask just where the stories came from. Writing about 1001 Nights, Husain Haddawy writes: "No one knows exactly when a given story originated, but it is evident that some stories circulated orally for centuries before they began to be collected and written down" (xi). Even though attributed to Mrabet, many of the stories (one thinks especially of those in Hadidan Aharam) he told Bowles had circulated in popular culture, perhaps for centuries.

The particular nature and circumstances surrounding Bowles's translation activities (notably, his work with oral tales, in close collaboration with the storytellers) heightens the intrinsic play of difference and instability in the act of translation, complicating the relationship between translator and "original" author. The status of an "original" is blurred, often effaced. "Who writes these books?" Greg Mullins asks at one point in his study, Colonial Affairs: Bowles, Burroughs and Choukri Write Tangier (114). "The line between author and translator is indistinct in any translation, but with Bowles it seems to disappear altogether," Gena Dagel Caponi asserts (131). Indeed, some contemporary readers proposed that the "translations" were Bowles's own inventions and that the Moroccan storytellers themselves were but part of the fiction. And Tahar ben Jelloun, the Moroccan Francophone writer who translated Choukri's novel into French (Le pan $n u$ ), suggested in a piece for 
Le Monde, "Une technique de viol," that the "translations" are Bowles's own writing in disguise, adding that "everything is wrong in this enterprise" (21).

Bowles's talent and skill as a writer prepared him well for the demands of a translator, recalling other accomplished writertranslators such as Ezra Pound, Robert Lowell, and W.S. Merwin. Archives housed in the University of Texas Harry Ransom Humanities Research Center and the University of Delaware Special Collections show how Bowles worked on drafts of works by Mrabet and others, editing with careful attention to language and storyline. Translation, thus, can be seen as an important supplement to or extension of his own writing. Both as a translator and as an editor, he sought to make these stories work in English, attentive to practical issues on the level of the sentence and narrative flow. Juan Gabriel Vásquez's proposition that the translator must often make a violation of the original applies here. The challenge of the translator, Vásquez has said in a recent New York Times Book Review piece, is "learning to be unfaithful to the original" (Vásquez). Violation need not be seen as a betrayal. Indeed, a too strict fidelity can result in producing a translation that does not do justice to the "original."

Bowles himself has said: "[They] are not exactly collaborations. I only get the authors to talk, you see. The stories are their own. My function is only to translate, edit, and to cut; now and then I have to ask a question to clarify a point" (qtd. in Evans, 53). He makes a similar claim in another interview, with Simon Bischoff:

But if there was a section that I didn't think belonged, I would tell the Moroccan: So, what does this mean? Or: Let's cut that out and go from here straight to here. That I did do. Or sometimes I would say: No one's going to understand this, you have to explain why, what it is. A Moroccan would understand, but a European won't know what's sous-entendu [between the lines]. It has to be explained! (245-46) 
To what extent, then, did Bowles influence the very nature of the stories that were told to him? As storytellers came to know the tastes and interests of their audience, how much did they craft and pitch their stories accordingly? Bowles's own attraction to the exotic and "primitive" has already been noted. How much Bowles had Western audiences in mind as he worked on translations-how much he preserved or even heightened that sense of otherness-is open to debate. Bowles himself, however, describes the operation of a dialogic process, at least with respect to the oral storytellers whose work he translated:

They knew what I liked from the beginning. When they began to record things for me, they saw my reactions, they saw that I liked certain things, such as violence, and bloodshed and hatred, and so on. So they specialized in that, in general. I don't think Choukri did that, no. His long novel I translated, For Bread Alone, had enough of violence and unpleasantness to please me. (Elghandor, 340)

The bulk of the stories he translated contain a distinctive sense of the exotic, a strangeness, or (at times) an atmosphere charged with potential fear or violence. That quality, no doubt, is part of their allure and charm. Bowles, here, might leave himself open to postcolonial critique and charges that his translations exoticize the text.

This calls to mind well-known recent debates in translation theory regarding domestication of the text vs. maintaining foreignness, brought to the fore by Lawrence Venuti in The Scandals of Translation: Toward an Ethics of Difference. Venuti proposes that the translation should "register the linguistic and cultural differences of the foreign text, sending the reader abroad" ("Translation" 210). These debates, it seems, are lodged within the context of the postcolonial condition. Bouchra Benlemlih touches on a number of thorny, nagging issues, notably the postcolonial context of Bowles's translation work in her thoughtful, thorough, 
theoretically informed study Paul Bowles' Literary Engagement with Morocco: Poetic Space, Liminality, and In-betweenness. Benlemlih notes that Bowles's translation activities are not only concerned "with the differences between languages, and with the difficulties attendant upon conveying messages from one language to the new syntactic, semantic and pragmatic systems of another" described by Douglas Robinson (2) but participate, as Robinson elaborates, in a movement "from one language to another, across power differentials marked off by the concepts of 'first world' and 'third world', 'anthropologist' and 'native', (3).

Here then is where translation and postcolonial theory intersect, with a consideration of unequal power dynamics that come into play as things are moved from one place to another. In Post-colonial Translation: Theory and Practice, Bassnett and Trivedi stress the manipulative force translation has in the transfer of meanings:

translation does not happen in a vacuum, but in a continuum; it is not an isolated act, it is part of an ongoing process of intercultural transfer. Moreover, translation is a highly manipulative activity that involves all kinds of stages in that process of transfer across linguistic and cultural boundaries. Translation is not an innocent, transparent activity but is highly charged with significance at every stage; it rarely, if ever, involves a relationship of equality between texts, authors or systems. (2)

Responding to these key insights in translation studies, Benlemlih draws our attention to the ways in which Bowles's translation activities are embedded in these hierarchies inherent in the postcolonial condition. She writes:

Translation, therefore, lies at the heart of the postcolonial condition. It reveals hierarchical power relations and the refractions of meaning imposed by the confrontations of different languages and cultures. Also, it produces hybrid 
'in-between' languages, languages out of the old dead ends which travel incessantly in search of the future in the metaphorics of exile, transit and movement. (53)

Indeed, Bowles's translations must be viewed within larger historical cultural conflicts between the Arab world and the West that take on specific inflections within personal relationships (love interests and friendships), often marked by tension and mistrust, largely resulting from the inherent, unequal conditions and preexisting stereotypes grounding those relationships. Frequently, for instance, those whose work Bowles translated had high, unrealistic expectations of monetary return, and blamed Bowles for cheating them when those expectations for compensation were not met. The resulting resentment stemming from those "hierarchical power relations" can be felt, for instance, in Choukri's famous public charges against Bowles in Paul Bowles wa 'uzla Tanja, where he attacked Bowles for homosexuality and exploitation of Moroccan men, claiming to know Arabic better than he did, and loving Morocco while hating Moroccans.

A distinctly sexual component is woven into the fabric of this dynamic, firmly lodged within an Orientalist erotics as well as an economy and politics of post-colonialism. While Joseph Allen Boone devotes just a page to Bowles in his recent monumental study, The Homoerotics of Orientalism, his readings of Bowles's photographs of both Yacoubi and Mrabet, pointing to their homoerotic qualities, certainly resonate:

Bowles' many portraits of the usually shirtless Mrabetwho remained his companion for decades-as well as photographs of the two men together taken with Bowles's camera thus not only record a fantasy of desirable otherness but document the lasting relationship between American expatriate and Moroccan writer. (392) 
This dynamic is clearly manifest in the translation process, as Greg Mullins attests to in his earlier study, Colonial Affairs. The chapter titled "Translating Homosexuality: Paul Bowles's Collaborations with Larbi Layachi, Mohamed Mrabet and Mohamed Choukri" demonstrates the complexities of these interactions, proposing that "the texts themselves were generated through literary encounters between Moroccans and a foreigner that in some way mimic the dynamics of an erotic encounter" (113).

I see these relationships between Bowles and those storytellers he translated as working in two ways, reciprocally, employing the kind of dialogic interaction Benlemlih (à la Bakhtin) highlights, not a oneway transaction-an equation of mutual benefit, or mutual exploitation in which power does not reside simply in one or the other participant. Still, without question, these interactions are fraught with all kinds of issues attendant to the postcolonial scene in which they play out. Like Benlemlih I see Bowles's translation work as part of his attempt to negotiate the "in-between" liminal space of exile, trafficking between native and adoptive homes (U.S. and Morocco), between one cultural scene and another, between one language and another. In addition to Bakhtin, Benlemlih draws on Mary Louis Pratt's notion of the "contact zone," both concepts being relevant to our considerations here as we think about translation and exile.

Certainly Bowles benefited from his translation work. It kept his name in circulation and brought modest monetary rewards. And, as I have argued elsewhere, Bowles's translation work had a distinct effect on his own writing style. His later stories are leaner, more "Moroccan" (Hibbard, 88; 102-3). The stories in later collections, beginning with One Hundred Camels in the Courtyard, stretching up to Midnight Mass and Unwelcome Words (all written during the time he was actively involved in the translation projects described) are written in a sparer style, and are often told from Moroccan perspectives. Read a Mrabet story and a Bowles story side by side and one senses not only stylistic affinities, but shared thematic preoccupationsdisplays of violence and revenge, transformative capacities of 
kif (a cannabis derivative), negotiations of sexuality and power, tensions between tradition and modernity, the presence of djinn, superstition, magic potions, and spells. Bowles's translation work and his fiction, thus, bleed into one another.

So, too, these storytellers benefited from their contact with Bowles. Indeed, without him, likely their stories never would have been transcribed and their own names would not have been brought to light as authors. Bowles was an important, in fact essential conduit, moving the stories from their Moroccan setting to a Western audience. His own reputation, the name recognition he had achieved through his own work as a writer (and composer), arguably helped him make the sale to U.S. publishers, reversing the usual relationship in which translators often ride on the fame of the writers whom they translate and are often relegated to the status of invisibility. This reality is seen in the books' presentation, as Benlemlih has aptly pointed out. Works such as Five Eyes and Love with a Few Hairs, for instance, are prominently billed on the front cover and book spines as 'translated and edited' by Paul Bowles. Bowles personally acted as agent, presenting and working out deals with publishers, and his name-established writer, author of The Sheltering Sky-is used prominently in the marketing of these books.

As with his involvement in preserving indigenous Moroccan music, Bowles's interest in the work of Moroccan storytellers was genuine. In response to Daniel Halpern's question about the importance of the Moroccan translations, Bowles states: "I think they provide a certain amount of insight into the Moroccan mentality and Moroccan customs, things that haven't been gone into very deeply in fiction" (Halperin, 98). As Benlemlih concludes, "Indeed, Bowles' translation project is a way to have Moroccan storytellers speak. They are speaking and not silenced subjects. They are not invisible or passive" (55). She goes on to point toward subversive potential in the project: "Bowles' translation project has the potential to disturb linear flows and power hierarchies" (57). First, the stories themselves often inscribe within them a critique consistent with postcolonial views, including autobiographical 
references and representations of exploitative relationships involving Moroccans and Europeans. Bowles's Moroccan collaborators, as mentioned, were (with the exception of Choukri) illiterate; and all came from poor backgrounds. Their stories frequently feature economic hardships and struggle. And-for instance in Layachi's $A$ Life Full of Holes and in Mrabet's Love with a Few Hairs and The Lemon-we see young Moroccan protagonists who, much like their authors, form imbalanced relationships with Western expatriatesnegotiating sexual terrain, economic exchange, and a desire to be independent. In Love with a Few Hairs, for example, Mohammed negotiates a relationship with a young Moroccan woman and with Mr. David, an expatriate with whom he sleeps. In scenes such as these, binaries between homosexuality and heterosexuality are deconstructed at the same time disparities between native Moroccans and Western outsiders are heightened. Lodged within various texts are critiques of the very dynamic Bowles and Mrabet are involved in. For instance, in Chocolate Dreams and Dollars, the young Moroccan Driss is depicted recording his stories before a tape recorder. The meta-quality is even more pronounced, perhaps in Mrabet's autobiography, Look and Move On, in which many passages depict the scene of translation: "One night Paul and I were busy translating a story ... I went in and told Paul. We finished the story. Then I said good-night and went out" (110).

Another dimension of this subversive potential lies in a process of circulation in which these writers, at first marginalized in their own countries then given enhanced credibility through the act of translation and publication in the West, now have begun to be made available to contemporary Moroccan audiences in a variety of forms. The contemporary Tanjaoui playwright, Zubeir ben Bouchta, for instance, has made a play, Nahr al hamra, (The Red Fire) based on the Bowles translation of the Yacoubi story "The Before Thinking," one of the stories in Five Eyes. And in 2004, the Moroccan Cultural Studies Center in Fez brought out (in English) a new edition of Mrabet's Love With a Few Hairs, with an introduction by Brian Edwards. Now Moroccan colleagues tell 
me that Abdel Aziz Jadir is working on an Arabic translation of that novel. We can reasonably expect this activity of translation and publication in Morocco to continue in the coming years. And with this, fresh analyses and perspectives of these works will no doubt emerge, ones that might possibly critique the conditions of their production.

Bowles's translation work is directly tied to his exilic condition. Without question, the space of exile provided him with conditions ripe for translation. It was in North Africa that he developed his knowledge of local languages, acquaintance with particular storytellers, and a desire to move works from one particular language and cultural scene to another. Through his translations, as Gena Dagel Caponi writes, "Bowles brought another point of view into the cultural discourse between Morocco and the West. In introducing such voices as those of the indigenous Moroccans, Bowles has been instrumental in creating what Edward Said has longingly described as a cultural counterpoint, in which several voices weave through and around each other, no one voice more privileged than any other, each of comparable interest and worth, all interdependent" (215). Regardless of criticisms, we must acknowledge that Bowles helped give voice to local Moroccan creative talents that otherwise would likely never have been heard.

\section{References}

Bassnett, Susan and Harish Trivedi. (Eds.) Post-colonial Translation: Theory and Practice. London and New York: Routledge, 1999.

Bejjit, Karim. “An American in Tangier: Interview with Paul Bowles.” Moroccan Cultural Studies Journal 1.1 (1999): 115-119. 
Ben Bouchta, Zoubeir. The Red Fire. Trans. Mustapha Hilal Soussi. Tangier: International Centre for Performance Studies, 2008.

Ben Jelloun, Tahar. "Une technique de viol.” Le Monde, 9 June 1972, 21.

Benlemlih, Bouchra. Paul Bowles' Literary Engagement with Morocco: Poetic Space, Liminality, and In-betweenness. New York: Peter Lang: Forthcoming.

Bischoff, Simon. "How Could I Send a Picture into the Desert?" Interview with Bowles, in Bischoff, Simon, (Ed.) Paul Bowles Photographs. Zurich: Scalo Publishers, 1994.

Boone, Joseph Allen. The Homoerotics of Orientalism. New York: Columbia U Press, 2014.

Bowles, Paul. Introduction. For Bread Alone. By Mohamed Choukri. London: Telegram, 2006. First published 1973.

. Music of Morocco: Recorded by Paul Bowles, 1959. Introd. and notes by Philip K. Schuyler. Atlanta: Dust to Digital, April 1, 2016.

. "Notes on the Work of the Translator." Five Eyes. Santa Barbara, Calif.:

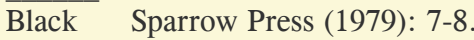

. The Pool, KIII. Tiberon, Cal, Austin, Tex. Cadmus Editions/Dom America, 2013. CD.

. "The Rif, to Music." Their Heads are Green. London: Peter Owen, 1963; New York: Random House, 1963; Ecco, 1984 (published as Their Heads are Green and Their Hands are Blue: Scenes from the Non-Christian World).

Caponi, Gena Dagel. Paul Bowles: Romantic Savage. Carbondale and Edwardsville: Southern Illinois University Press, 1994.

Choukri, Mohamed. Paul Bowles wa 'Uzla Tanja. (Paul Bowles and the Solitude of Tangier ). Tangier: Altopress, 1996. 
Edwards, Brian T. Morocco Bound: Disorienting America's Maghreb, from Casablanca to the Marrakech Express. Durham: Duke U Press, 2005.

Elghandor, Abdelhak. "Cross-Cultural Encounters and the Image of the Other in Paul Bowles’ Fiction.” Diss. University of Ohio, 1994.

Evans, Oliver. Interview. Caponi, Gena Dagel, ed. Conversations with Paul Bowles. Jackson: University Press of Mississippi, 1993.

Halperin, Daniel. Interview. Caponi, Gena Dagel, ed. Conversations with Paul Bowles. Jackson: University Press of Mississippi, 1993.

Haddawy, Husain. Intro. The Arabian Nights. New York: Norton, 1990.

Hibbard, Allen. Paul Bowles: A Study of the Short Fiction. New York: Twayne, 1993.

Layachi, Larbi. A Life Full of Holes. Trans. Paul Bowles. New York: Grove Press, 1964.

Maier, John R. Desert Songs: Western Images of Morocco and Moroccan Images of the West. Albany, NY: State University of New York Press, 1996.

Mrabet, Mohammed. Chocolate Creams and Dollars. Taped and trans. Paul Bowles. New York: Inanout Press, 1991.

. Hadidan Aharam. Trans. Paul Bowles. Santa Barbara, CA: Black Sparrow, 1973.

. The Lemon. Trans. Paul Bowles. London: Peter Owen, 1969.

. Look and Move On. Trans. Paul Bowles. Santa Barbara, California: Black Sparrow Press, 1976.

. Love with a Few Hairs. Trans. Paul Bowles. London: Peter Owen, 1967. 
Mullins, Greg A. Colonial Affairs: Bowles, Burroughs, and Chester Write Tangier. Madison: U of Wisconsin Press, 2002.

Robinson, Douglas. Translation and Empire: Postcolonial Theories Explained. Manchester: St. Jerome Publishing, 1997.

Stewart, Lawrence D. Paul Bowles: The Illumination of North Africa. Carbondale: Southern Illinois University Press, 1974.

Vásquez, Juan Gabriel. "By the Book." New York Times Book Review. 30 July 2015. Web. 24 June 2016. http://www.nytimes.com/2015/08/02/books/review/ juan-gabriel-vasquez-by-the-book.html?_r=0. Accessed July 3, 2017.

Venuti, Lawrence. The Scandals of Translation: Toward an Ethics of Difference. New York: Routledge, 2002.

. "Translation as a Cultural Poetics: Regime of Domestication in English." Textual Practice 7.2 (1993).

Young, Daniel, dir. The Cage Door Is Always Open. Hesse Greutert Film, 2013.

Recebido em: $13 / 08 / 2017$

Aceito em: 10/10/2017

Publicado em janeiro de 2018

Allen Hibbard teaches courses in Modern American literature, criticism, backgrounds of modern literature, the modern novel, postmodernism, and Middle-Eastern literature and culture. He is the author of a book on Paul Bowles' short fiction and is completing a biography of Alfred Chester. From 1992 to 1994, he was a Fulbright Lecturer at the University of Damascus, Syria. Murfreesboro, USA. E-mail: allen.hibbard@mtsu.edu 